\title{
The Effect of Strategic and Online Planning on Accuracy of L1 Learners' Written Production
}

\author{
Asghar Salimi (Corresponding author) \\ Department of English, University of Maragheh, Maragheh, Iran \\ E-mail: Asgharsalimi356@gmail.com \\ Elham Khayef \\ Department of Teaching English as a Second Language, Sarab Branch, Islamic Azad University, Sarab, Iran \\ E-mail: Khayef.elham@yahoo.com \\ Davood Amini \\ Department of English, Azarbaijan Shahid Madani University, Iran
}

Received: 01-05- 2015

Published: 01-11- 2015
Accepted: 14-07- 2015

doi:10.7575/aiac.ijalel.v.4n.6p.148
Advance Access Published: August 2015

URL: http://dx.doi.org/10.7575/aiac.ijalel.v.4n.6p.148

\begin{abstract}
In recent years, the application of writing tasks has effectively shed lights on promoting learners' written production. Research on SLA stresses the importance of tasks in the case of complexity, fluency and accuracy (Foster, 1997, 2001; Givon, 1985; Robinson, 2001; Skehan, 1998), since they have had fluctuating impact on L2 learning. However, what is neglected in the literature is the impact of writing task on learners' first language written production that in most cases has paved the way for transmitting ideas in L2. Therefore, the essential aim in the present study is to investigate the effect of strategic planning time and on - line planning time on accuracy of first language learners' written production. To attain the goal, two classes of $6^{\text {th }}$ grade school students $(n=32, n=24)$ were selected. The students did the writing task in the first session which was considered as a pretest in the study. Following a weekly "time out", in the class A (n $=32)$ strategic planning time was presented to the students and in the class B $(n=24)$, on - line planning time was conducted for ten minutes proceeding writing task. Time limit to complete the writing production was 30 minutes in both classes. The collected written data was quantified in terms of accuracy measure. Paired sample T-tests and independent sample T-test were conducted to statistically analyze data. The obtained results revealed that strategic planning led to much accuracy in post task in terms of L1 written production compared to pre task. However, the result of statistical analysis in on - line planning time was not significant, since it didn't result in students' L1 writing progress.
\end{abstract}

Keywords: strategic planning time, online planning time, written production, accuracy

\section{Introduction}

To accomplish writing tasks in a variety of roles, adults are able to utilize writing process that integrates knowledge, skills, and strategies in the best way. They consider the purpose and audiences for communicating in writing. Information is presented and organized to serve the purposes, contexts and audiences. They also take language usage, including grammar, spelling, and sentence structure into consideration to minimize hurdles to reader's comprehension. In recent perspective of writing instruction, coupling of grammar instruction and writing gives learners the chance to communicate meaningfully and appropriately (Birch, 2005; Byrd, 2005; Frodesen, 2001; Frodesen \& Holten, 2003) since despite years of instructing writing skill in schools, limited lexical and syntactic sources of conversational discourse persists in writing. Within second language (L2) writing field, most of the existing researches have been devoted to writing in English as a second or foreign language. However, producing words in the first language which is the dominant language of the learners can take place in a faster rate than their foreign language. With respect to the picture naming studies, the production of words in a foreign language requires much more time and effort rather than the first language (e.g., chen \& Leung, 1989; Kroll \& Curley, 1988, Potter, So, Von Eckardt, \& Feldman, 1984). Since writing is one of the essential skills in Language learning, it has been regarded as a neglected skill in L1.

The objective in this paper is to find ways to motivate and boost L1 learners' written production following strategic and on - line planning times by giving them writing task.

\section{Literature Review}

Considering a variety of studies conducted in the favor of task - based approach (Candlin, 1987; Long, \& Crooks, 1992; Long, 1985; Prabhu, 1987; Rahimpour, 2009, Robinson, 1995; Ellis, 2005), the domain has witnessed plenty of ups and downs in the past few years. Anxiety, familiarity with the topic, learners' proficiency level, the type, structure, and condition of task constrained heavy burden over language learners' production speed and the complexity of their utterance, when they wrote or spoke (Rahimpour, 1997, 1999, 2008). Long $(1983,1989)$ declared that the role of 
interaction in task - based language learning is essential. He entailed that negotiation of meaning pertains to the way learners overcome communicational difficulties while completing the task. Learners' interactional adjustment affect such difficulties, serve to persuade their interlocutors to modify learners' provided input. A number of studies have been carried out on the role of pre - task planning which aimed at preparing students to perform the task in ways that would promote acquisition (Ellis, 2001). Lee (2000) claimed that framing task is essential since it supplies an advance organizer of what the learners entail to do and the nature of outcome they arrive at. Dornyei (2001) stated that task should be presented in ways that motivate learners. Some researchers (crooks, 1989; Ellis, 1987) discussed about the relationship between planning and complexity, fluency, then accuracy. A great bulk of research (Foster \& Skehan, 1996, 1999; Mehnert, 1998; Ortega, 1999; Skehan \&Foster, 1997, 1999) has been conducted to pinpoint the positive effect of planning time on complexity and fluency.

Foster and Skehan (1999) stated that source of planning and focus on planning effects on task- based performance. The obtained results showed that the teacher - oriented condition significantly influenced on accuracy whereas condition which was planned alone directed to more complexity, fluency and turn length.

Skehan and Foster (1999) studied the impact that task structure and processing load had on L2 learners' performance doing a narrative retelling task. Two tasks were provided in the study, one structured (restaurant) and the other unstructured (golf). The researcher believed that the former task was predictable to the viewer while the latter was unpredictable and lacked interconnectedness. To influence the processing load of the task four conditions were utilized to watch the video: Describing the story while watching it, making outline of the story before watching it, watching the video first and describing the story while watching it again, watching the video and retelling it in their own time. The obtained results indicated that fluent speech was the result of structured task in all four conditions. Processing load influenced the language complexity. In the case of accuracy, task as well as condition had no significant effects.

Iwashita, et al. (2001) proposed that planning time as well as other factors including adequacy, perspective had no effect on accuracy. However, it had an effect on immediacy dimension.

Yuan and Ellis (2003) investigated the impact that on - line planning and pre-task have on learner's monologic oral production. It was conducted at three phases including: no planning, a ten-minute pre-task planning, and unlimited time on-line planning to narrate the story. The obtained results demonstrated that on - line planning outperformed the other phases in producing more accurate language. It has been unclear so far that whether planning influenced on accuracy.

Some researchers (Foster \& Skehan, 1996; Skehan \& Foster, 1997; Mehnert, 1998) stated that planning leads to increase in accuracy, but others (Crooks, 1989, Ortega, 1999, Wigglesworth, 1997, 2001) pointed out that planning does not affect on increase in accuracy. In fact, the effect of complexity and fluency is higher than accuracy. Moreover, on line planning (Wendel, 1997; Yuan \& Ellis, 2003) that is - the container to which someone's resources is rearranged and planned while a task is being applied - probably directs to learners' accuracy. However, the main purpose of the present paper is to investigate the effect of strategic and on - line planning times on L1 learners' written production following giving them written task.

\section{Methodology}

\subsection{Research Question and Hypothesis}

RQ: will strategic planning result in more accuracy than on - line planning in writing task of sixth grade female students L1 written production?

H0: there is no statistical difference between the accuracy of L1 written production in strategic and on - line planning groups.

H1: there is a statistical difference between the accuracy of L1 written production in strategic and on - line planning groups Participants

\subsection{Participants}

The participants of the study were 56 female 6th grade school students who were registered in Massoudpei primary school in north west Guilan, Astara, Iran. There were two $6^{\text {th }}$ grade classes in the school contained 32(class A) and 24 (class B) pupils in each class. The students had started sentence writing in their $3^{\text {rd }}$ grade and following two school years, they were able to write in different topics regarding to their ages which ranged between 12 - 13 .

\subsection{Procedure}

Both groups of learners received pre task which was regarded as pretest. The provided task was pictorial. After a week time interval, for 32 population class strategic planning time was presented for 10 minutes proceeding written production and they were asked to write as they were taught. In fact the teacher discussed the task with students, giving them some ideas regarding to the presented task to brain storm. Yuan and Ellis (2002) pointed out that allowing students unlimited time to perform a narrative task resulted in more complex and more accurate language than the task which one constrained time limit. Lee (2000) severely suggested setting strict time limits since it effected students' language production. For 24 population class, on - line planning time was presented and students were assisted whenever they requested for while writing. The post tasks were regarded as post tests for both groups. The collected data was quantified and SPSS was conducted to analyze data. Two paired sample T- tests were applied to compare the 
pre and post tests in both groups. The independent sample T-test was conducted to compare strategic and on - line planning means to pinpoint which one outperform the other.

\section{Data analysis and results}

The obtained quantified data were fed into SPSS software. T - test was conducted as the statistical means of analysis for comparing the means of pre and post tests of each 2 groups (strategic, on - line) in accuracy of written production, as well as both groups' post tests.

Table 1.Paired sample T-test for the comparison of the accuracy scores pre-test and post test in strategic planning

\begin{tabular}{lllll}
\hline & $\mathrm{N}$ & Mean & Std. Deviation & Std. Error Mean \\
\hline Pre test accuracy & 32 & .70 & .136 & .024 \\
\hline Post test accuracy & 32 & .82 & .144 & .025 \\
\hline
\end{tabular}

Table 1 indicates the result of descriptive statistics for the accuracy in L1 written production of pre test and post test in terms of strategic planning time. It can be concluded that there was a significant increase in accuracy scores from pretest (time 1) to post test (time2).

Table 2. Paired sample T-test for comparison of pre and post tests accuracy score in strategic planning

\begin{tabular}{|c|c|c|c|c|c|c|c|c|c|}
\hline & \multicolumn{9}{|c|}{ Paired Differences } \\
\hline & & & & $\begin{array}{l}95 \% \mathrm{Co} \\
\text { Interval } \\
\text { Differes }\end{array}$ & $\begin{array}{l}\text { fidence } \\
\text { of the } \\
\text { ce }\end{array}$ & & & & \\
\hline & Mean & $\begin{array}{l}\text { Std. } \\
\text { Deviation }\end{array}$ & $\begin{array}{l}\text { Std. } \\
\text { Error } \\
\text { Mean } \\
\end{array}$ & Lower & Upper & $\mathrm{t}$ & $d f$ & $\begin{array}{l}\text { Sig. } \\
\text { tailed) }\end{array}$ & (2- \\
\hline $\begin{array}{l}\text { Pre Strategic } \\
\text { Post } \\
\text { Strategic }\end{array}$ & -.1181 & .15194 & .02686 & -.1729 & -.0633 & -4.398 & 31 & .000 & \\
\hline
\end{tabular}

A paired sample t-test was conducted to evaluate the impact of the strategic planning on student's L1 written production accuracy score. There was a statistically significant increase in accuracy scores from pretest (time 1$)(\mathrm{M}=.70, \mathrm{SD}=.136)$ to post test (time2) $(\mathrm{M}=.82, \mathrm{SD}=.144, \mathrm{t}(31)=-4.39, P<.0005$ (two tailed). The mean increase in written accuracy production scores was .118 with a $95 \%$ confidence interval ranging from -.172 to -.063. The Eta Squared statistic ( 0.38 ) indicated a large effect size.

Table 3.Paired sample T-test for the comparison of the accuracy of written production in on-line planning

\begin{tabular}{lllll}
\hline & $\mathrm{N}$ & Mean & Std. Deviation & Std. Error Mean \\
\hline Pre test accuracy & 24 & .719 & .20128 & .04109 \\
\hline Post test accuracy & 24 & .773 & .15555 & .03175 \\
\hline
\end{tabular}

Table 3 demonstrates the result of descriptive statistics for the accuracy of L1 written production in pre test and post test in terms of on-line planning time. It can be concluded that there was a significant increase in accuracy scores (mean) from pre- test (time 1) to post test (time2).

Table 4. Paired sample T-test for comparison of pre and post tests accuracy score in strategic planning

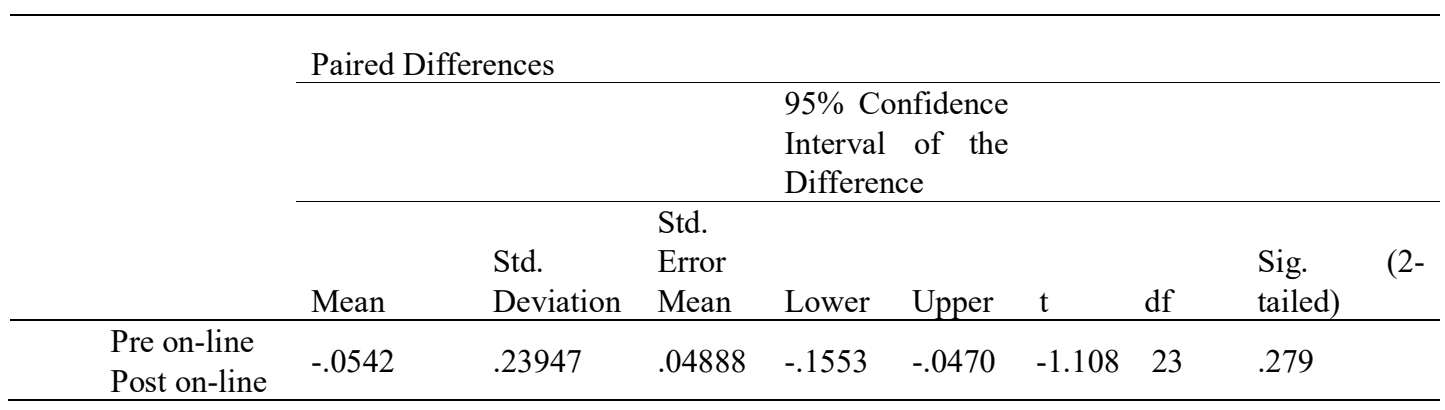


A paired sample t-test was conducted to evaluate the impact of the on - line planning time on student's written production accuracy scores. There was no statistically significant difference in accuracy scores from pretest (time 1) $(\mathrm{M}=.719, \mathrm{SD}=.2012)$ to post test (time2) $(\mathrm{M}=.773, \mathrm{SD}=.15555, \mathrm{t}(23)=-1.108, P>.0005$ (two tailed). The mean increase in accuracy scores was -.054 with a 95\% confidence interval ranging from -.1553 to -.0470. The Eta Squared statistic (.049) indicated a small effect size.

Table 5. Shows the result of descriptive statistic for the comparing means of strategic and on-line planning

\begin{tabular}{lllll}
\hline Grouping & $\mathrm{N}$ & Mean & Std.Deviation & Std. Error Mean \\
\hline Accuracy strategic & 32 & .8336 & .0840 & .0224 \\
\hline Accuracy on-line & 24 & .7700 & .15817 & .0329 \\
\hline
\end{tabular}

Table 5shows the means of accuracy in written production for both groups. It indicates that participants receiving strategic planning instruction outperformed on - line planning time group in terms of accuracy in written production.

Table 6. Independent sample t-test for the means of strategic and planning times post tests

\begin{tabular}{|c|c|c|c|c|c|c|c|c|c|}
\hline & $\begin{array}{l}\text { Leve } \\
\text { For } \mathrm{E} \\
\text { Varia }\end{array}$ & $\begin{array}{l}\text { Test } \\
\text { ality } c\end{array}$ & & & & $\begin{array}{l}\text { T-test for } \\
\text { Means }\end{array}$ & Equality of & & \\
\hline & $\mathrm{F}$ & Sig. & $\mathrm{t}$ & df & $\begin{array}{l}\text { Sig. } \\
(2 \\
\text { tailed })\end{array}$ & $\begin{array}{l}\text { Mean } \\
\text { Difference }\end{array}$ & $\begin{array}{l}\text { Std. Error } \\
\text { Difference }\end{array}$ & $\begin{array}{l}\text { 95\%Confidence } \\
\text { Interval of the } \\
\text { Difference }\end{array}$ & \\
\hline & & & & & & & & Lower & upper \\
\hline $\begin{array}{l}\text { Equal } \\
\text { variance } \\
\text { assumed }\end{array}$ & 3.23 & .081 & 1.38 & 35 & .175 & .063 & .0459 & -.0296 & .1568 \\
\hline $\begin{array}{l}\text { Equal } \\
\text { variance } \\
\text { not } \\
\text { assumed }\end{array}$ & & & 1.59 & 34.56 & .120 & .063 & .0399 & -.0174 & .1446 \\
\hline
\end{tabular}

An independent sample T-test was conducted to find out if strategic planning and on-line planning groups differed on the receptive post tests. An examination of data indicated that There was a significant difference in accuracy scores of strategic planning $(\mathrm{M}=.8336, \mathrm{SD}=.0840, \mathrm{~N}=32)$ and on - line planning $(\mathrm{M}=.7700, \mathrm{SD}=.1581, \mathrm{~N}=24)$. The $95 \% \mathrm{CI}$ for the difference in mean is $-.0296, .1568(\mathrm{t}=(35)=1.33, P=\ldots$, two tailed). The magnitude of the differences in the means (mean differences $=.063 .95 \%$ CI: -.029 to .156$)$ was very small (Eta Squared $=.006)$.

According to table 6, there was no significant difference between the performance of two groups in post - test. As a result, the null hypothesis stating that "there was not any significant difference between the accuracy of L1 written production in strategic and on - line planning" is confirmed.

\section{Discussion and Conclusion}

Regarding to the obtained results of statistical analysis for the effect of strategic and on - line planning times on the accuracy of L1 learners' written production, it was revealed that the two groups' performance was not statistically significant, although the mean of accuracy of strategic group was higher than on- line planning group. The findings of the present study are in line with Crooks (1989) and Ellis (1987), which caused controversy over being connections between planning and, complexity and fluency (crooks) and accuracy (Ellis), respectively. A great number of studies (Foster \& Skehan, 1996, 1999; Mehnert, 1998; Ortega, 1999; Skehan \&Foster, 1997, 1999) have made a vast effort to find out how planning effects task performance (complexity and fluency). Although in the case of accuracy nothing has been surely confirmed. However, the findings of the study deviated from the studies like Crooks (1989), Ortega (1999), Wigglesworth $(1997,2001)$ who pointed out that planning time leads to reduction in accuracy. They also stated that many factors and conditions generate accuracy effects. However, the findings of these researchers (Foster \& Skehan, 1996; Mehnert, 1999; Skehan \&Foster, 1997) are in line with the results of our study in post test. Taking strategic and on - line planning into consideration, strategic planning involved learners to priorities content over form or whether they are given guidance in what to plan(Ellis, 2006) or even as Sangarun (2001) stated focus their attention to form and content together, which led to accuracy in writing.

This paper has attempted to suggest some of the ways that both planning times (on-line \& strategic) can be of considerable theoretical and practical relevance to teachers, trainers, teacher educators preparing individuals to teach writing in L1 classroom. Writing instruction must assist learners to unlock their creative and expressive abilities 
accompanied by accuracy. Meanwhile textbooks and content of teaching materials play crucial roles to construct a high quality of education. Producers of textbook materials and textbook designers should improve the learning materials in schools to direct toward TBLT. The present study has also some limitations that need to be mentioned. First, the writing production is a long - lasting obtained skill which needs to be taken into account in schools. Even in L1 state schools it is a neglected skill. Directing learners' attention to different strategies which suit their learning style in first stages of school life would be useful and efficient to pave the way for them in the advance levels to attain appropriate and accurate production. Second, learners' individual differences were not taken into consideration in the study since each individual learner utilizes particular style in production. Third, in both forms of planning times the mentioned strategies (on-line \& strategic) were operated once in a short period of time interval (one week). It would be suitable and efficiently effective to be used during school period while writing to motivate learners' awareness concerning how to write and what to take into account while writing. Fourth, giving learners one task at a time will motivate them to write better, but giving the same task twice or repeatedly demotivate them and lead to failure in the post task.

\subsection{Pedagogical implications}

The present paper has as much pedagogical implication for L1 and L2 language trainers, educators and SLA researchers as task and syllabus designers. The language trainers and educators are required to find ways to motivate and involve learners in the process of written production since it is one of the neglected skills. The school students should be provided a variety of strategies to help them attain the writing goals in school. Teachers should assist learners to put their path through variety of strategies which they benefit from. It is worth noting that accuracy is as essential as complexity and fluency. It deserves much more attention from the side of L1 as well as L2 learners and teachers.

\section{References}

Birch, B. (2005). Learning and Teaching English Grammar. K-12 Prentice Hall, White Plains, NY

Byrd, P. (2005). Instructed grammar. In: Hinkel, E. (Ed.), Handbook of Research in Second Language Teachin and Research. Lawrence Erlbaum, Mahwah, NJ, pp. 545-562.

Candlin, C. (1987). Toward task - based language learning. In Candlin, C. \& Murphy, D. (Ed.), Language Learning Tasks (pp. 5-22). Englewood Cliffs, NJ: Prentice Hall.

Chen, H.-C. \& Leung, Y., -S. (1989). Patterns of Lexical Processing in a non native language. Journal of Experimental psychology: Learning, Memory, and Cognition, 12, 397 - 401.

Crooks, G. (1989). Planning and interlangugae variation. Studies in Second Language Acquisition, 11, 367-83.

Dornyei, Z. (2001). Motivational strategies in the classroom. Cambridge, Cambridge University Press.

Ellis, R. (1987). Interlanguage validity in narrative discourse: Style shifting in the use of the past tense. Studies in Second Language Acquisition, 9, 12-20.

Ellis, R. (2001). Investigating form-focused instruction. In R. Ellis (Ed.), Form-focused instruction and second language learning (pp. 1-46). Malden, MA: Black well publishers.

Ellis, R. (2005). Planning and task performance in a second language. Amsterdam: John Benjamins .

Ellis, R. (2006). The methodology of task-based teaching. Asian EFL Journal: English Language Teaching and Research Article. University of Auckland.

Foster, P. (2001). Lexical measures in Task - based performance. Paper presented at the AAAL Conference, Vancouver, Canada.

Foster, P. \& Skehan, P. (1996). The influence of planning on performance in task - based learning. Studies in Second Language Acquisition, 18 (3), 299-324.

Foster, P. \& Skehan, P. (1999). The effect of source of planning and focus of planning on task - based performance. Language Teaching Research, 3(3), 185-214.

Frodesen, J. (2001). Grammar in writing. In: Celce-Murcia, M. (Ed.), teaching English as Second or Foreign Language, $3^{\text {rd }}$. edition. Heinel and Heinle, Boston, pp. 233-248.

Frodesen, J., Holten, C. (2003). Grammar and the ESL writing class. In: Kroll, B. (Ed.), Exploring the Dynamics of Second Language Writing. Cambridge Applied Linguistics, pp. 141-161.

Givon, T. (1985). Function, structure, and language acquisition. In D. Slobin (Ed.), The cross-Linguistic Study of Language acquisition, Hillsdale, N. J.: Lawrence Erlbaum, $100-1028$.

Iwashita, N., McNamara, T., \& Elder, C. (2001). Can we predict task difficulty in an oral proficiency test? exploring the potential of an information-processing approach to task design. Language Learning, 51(3), 401-436.

Kroll, J. F. \& Curley, J. (1988). Lexical Memory in Novice Bilinguals: the role of concept in retrieving second language words. In M. M. Grunenberg, P. E. Morris \& R. N. Sykes(eds.), Practical aspects of Memory: Current Research and Issues. Chichester: John Wiley.

Lee, J. (2000). Tasks and Communicating in Language Classroom. Boston: McGrew-Hill. 
Long, M. (1983). Native speaker/non- native speaker conversation and the negotiation of comprehensible input. Applied Linguistic, 4(2), 126-41.

Long, M. (1985). A role of instruction in second language acquisition: task-based language teaching. In K. Hyltenstam \& M. Pienemann (Ed.), Modeling and assessing second language acquisition (pp. 77-99). Cleveland: Multilingual Matters.

Long, M. (1989). Task, group, and task - group interaction. University of Hawai'I Working Papers in English as a Second Language, 8(2), 1-26.

Long, M. H., \& Crookes, G. (1992). Three approaches to a task-based syllabus design.TESOL Quarterly, 26(1), 27-49.

Mehnert, U. (1998). The effects of different length of time for planning on second language performance. Studies in Second Language Acquisition, 20, 83-108.

Ortega, L. (1999). Planning and focus on form in L2 oral performance. Studies in Second Language Acquisition, 21, $109-48$.

Potter, M. C., So, K. F., Von Eckardt, B. \& Feldman, L. B. (1984). Lexical and conceptual representation in beginning and proficient bilinguals. Journal of Verbal Learning and Verbal Behavior, 23, 23 - 38.

Probhu, N.S. (1987). Second Language Pedagogy. Oxford: Oxford University Press.

Rahimpour, M. (1997). Task complexity, task condition, and variation in L2 oral discourse.Unpublished Ph.D. thesis, University of Queensland, Australia.

Rahimpour, M. (1999). Task complexity and variation in interlanguage. In N.O. Jungheim\& P. Robinson (Ed.), pragmatic and pedagogy: Proceeding of the $3^{\text {rd }}$ Pacific Second Language Research Forum (pp. 115- 134). Tokyo, Japan: Pac LRF.

Rahimpour, M. (2008). Implementation of task - based approaches to language teaching. Pazhuhesh-e-zabanha-yekharejeh Journal, University of Tehran.

Rahimpour, M. (2009). Theoretical and practical issues in task-based language teaching and syllabus design. Plenary speaker at the $7^{\text {th }}$ international TELLSI conference, October, 20-22, University of Yazd, Iran.

Robinson, P., Chi-chien Ting, S. \& Urwin, J. (1995). Investigating second language task complexity. RELC 26. PP:6278.

Robinson, P. (2001). Task complexity, cognitive load, and syllabus design. In P. Robinson (Ed.), Cognition and second language instruction, Cambridge, University Press.

Sangarun, J. (2001). The effect of pre-task planning on foreign language performance. Doctoral thesis, University of Toronto, Canada.

Skehan, P. (1996). A framework for the implementation of task-based instruction. Applied Linguistics, 17, 38-72.

Skehan, P. (1998). A cognitive approach to language learning. Oxford: Oxford University Press.

Shehan, P. \& Foster, P. (1997). The influence of planning and post - task activities on accuracy and complexity in task based learning. Language Teaching Research, 1(3).

SKehan, P. \& Foster, P. (1999). The influence of task structure and processing condition on narrative retelling. Language Learning, 49(1), 93-120.

Wendel, J. (1997). Planning and second language narrative production, unpublished doctoral dissertation, Temple University Japan.

Wiggleworth, J. (1997). An investigation of planning time and proficiency level on oral test discourse. Language Testing, 51, 303-46.

Wiggleworth, J. (2001). Influence on performance in task-based oral assessment. In Bygate, Skehan \& Swain (Eds.).

Yuan, F. \&Ellis, R. (2002). The effect of pre-task planning and on-line planning onfluency, accuracy, and complexity in L2 oral production. Applied Linguistics, 24(1). 